\title{
Efforts to formalise international collaboration in scholarly information infrastructure
}

Stephen Cramond

Stephen Cramond is Electronic Information Resources Librarian, University of Adelaide.

Keywords Australia, Library Consortia, Collaborative alliances, Databases, Subject gateways, Authentication mechanisms

[This is the author's version of a work that was accepted for publication as: Stephen Cramond, (1999) "Efforts to formalise international collaboration in scholarly information infrastructure", Library Hi Tech, Vol. 17 Iss: 3, pp.272 - 282]

Abstract This article describes recent attempts to formalise relationships between the university sector in Australia, and equivalent bodies in the UK and the USA, in the development of information infrastructure through the creation of international liaison positions. The article provides a historical overview for collaborative activity of this kind, and gives an organisational perspective on the current developments. It describes the process by which potential issues for international collaboration were selected, discusses the opportunities for collaboration in each - library purchasing consortia, subjectbased information gateways, mirroring of databases, authentication systems, and the scholarly communications crisis - and reports on progress with those issues. The strengths and weaknesses of this formal, nation-to-nation approach are also discussed.

\section{Background to the collaboration}

For several years, the Australian university sector has sought to develop formal collaborative links with international partners in the development of faster, more reliable and more affordable access to Web resources. It has been joined in some of these activities by the National Library of Australia which has a strong commitment to international collaboration. This article describes the particular efforts of the Australian university sector to develop formal collaborative links with international partners in the area of information infrastructure. "Information infrastructure" is understood here to mean not only physical infrastructure. It also includes the organisational issues that allow for the more felicitous flow of scholarly communications - issues such as authentication mechanisms, mirroring of databases, but also appropriate intellectual property policies and practices, and support for cooperative cataloguing of Web resources.

Australia, as a distant and sparsely populated continent is well-known for its rapid uptake of technological innovation, and for its abiding interest in engagement with other countries and cultures.

Beyond the broad cultural factors at play in encouraging the nation to face outwards, Australians are committed - at a national level - to being an important and successful part of the international academy. Australians are disproportionately productive members of the international academic community, and are therefore highly dependent both on the scholarly output - the books, journals, and databases - of other countries, and on the technological infrastructure required for its dissemination. Taken together, these factors make Australia unusually interested in and sensitive to international developments, and not only willing, but often feeling itself driven, to engage and collaborate with others. 
The most recent instances of such collaboration have their inspiration in two circumstances, one technological and the other socio-political. On the technology front, the advent of the Internet provided in itself both the raison d'etre and the means for such collaboration. In terms of social and political organisation Australia lies - very roughly - half way between the centralised, publicly funded higher education system in the UK, and the more decentralised, privately funded scene in the USA. This, together with Australia's more recent and benign history as a British colony leads Australians, in an instinctive way, to look to UK experience when seeking examples of best practice in governmental initiative. The various responses in the UK to the impact of advances in computer networking, culminating in the UK Higher Education Libraries Review (also known as the Follet Report) and the targeted expenditure on UK university library infrastructure that flowed from it were therefore closely studied in Australia (Rusbridge, 1998).

Given Australia's smaller population, and comparatively decentralised political framework, the country cannot exactly mimic what the UK does. There is, for example, no equivalent of the UK Higher Education Funding Councils (HEFCS), nor of their Joint Information Systems Committee (JISC), a body that takes central funding from the HEFCs, and provides the UK higher education sector with its information infrastructure. Instead, there are a series of essentially voluntary standing committees, paid for by the 38 publicly funded universities on a subscription basis. These are, the Australian ViceChancellors' Committee (AVCC), the Council of Australian University Librarians (CAUL), and the Council of Australian University Directors of IT (CAUDIT). AVCC is the peak organisation representing Australian higher education nationally and internationally. It acts as a lobby group on behalf of the sector to the Australian federal government and sets out broad policies and guidelines for its members. AVCC also manages AARNet, that part of the Internet in Australia available to the universities. CAUL and CAUDIT also act as lobbies, and have an information-sharing role for their members. Increasingly, they provide an organisational framework for initiatives in cooperative development for the university sector as a whole.

In this context the example of the Follet Report was important, as it provided much of the inspiration for the range of programs pursued when, in 1993, the Australian federal government funded the National Priority (Reserve) Fund (NP(R)F) for university library infrastructure. The NP(R)F program provided $\$ 5$ million in grant moneys - available over five years - for the development of Australian university library infrastructure. While this did not compare with the $f 100$ million available in the UK under Follet, NP(R)F was crucial in two ways in the development of international collaborative activity. First, it allowed Australia to copy relevant UK initiatives. For example, in the UK the University of Bath ISI Data Service (BIDS) service, beginning in 1991, broke new ground by offering Internet access to the ISI Citation Indexes for the entire UK higher education sector (Morrow, 1992). In Australia, NP(R)F funding would not stretch quite that far, so first, through the National Library, and then through Ovid Australia and the Unilinc Data Centre in Sydney, the entire Australian university community gained Internet access to ISI's current contents through a consortium deal negotiated by CAUL. Support was also made available under NP(R)F for discounted access to other services, such as OCLC and CSA databases.

Second, NP(R)F funding made possible direct collaboration among Australian, UK, and American partners, most obviously in the joint electronic document delivery software (JEDDS) electronic document delivery project.

JEDDS, in fact, continues to be the signal example of fruitful collaboration. A partnership between elements of the Follet-funded eLib program (administered by JISC), the NP(R)Ffunded project at Griffith University, Brisbane, Australia and the Research Libraries Group (RLG), JEDDS developed RLG's ARIEL software to allow for integration with ILL management systems, and the e-mail delivery of scanned images of articles. JEDDS has itself evolved beyond this, into the local interlending and 
document delivery administration system (LIDDAS) - a full-scale attempt to automate interlibrary loan operations. This has in turn spawned collaboration with European partners in the European Unionfunded PRIDE project which aims at facilitating authentication for global access to library services (McLean, 1999a).

With no JISC equivalent in Australia, it was the AVCC's responsibility to administer the NP(R)F funds, first through its Standing Committee on Information Resources (SCIR) and, from 1998 the Standing Committee on Information Policy (SCIP). Both SCIR and SCIP included senior officers from CAUL and CAUDIT in their memberships.

Contact between CAUL and JISC members therefore flourished while the eLib and NP(R)F programs developed. These contacts led in late 1996 to the first of two meetings between representatives from the JISC, CAUL and AVCC, and then in 1997 between JISC, CAUL, CNI (Coalition for Networked Information) and others in the UK.

The notion of formalising the relationship created through these contacts was sealed following the second meeting (Beyond the Beginning, 1997) held in London in July 1997 when representatives from CAUL met with their UK and American counterparts.

The London meeting provided an opportunity for a focused discussion on the need for, and possible nature of, international collaboration in the development of common information infrastructure between the two countries.

One immediate consequence of the meeting was the creation of the position of International Coordinator for JISC, within the eLib office in the UK, and the subsequent striking of a "JISC/ Caul collaboration agreement" (Russell, 1997). The creation of the UK position preceded and inspired the creation of an Australian equivalent. This position, executive officer, information infrastructure liaison, was funded by a grant from the National Priority (Reserve) Fund for an initial period of 12 months, starting in late January 1998. Given the fact that the AVCC administered the NP(R)F program, the executive officer reported to the AVCC's Standing Committee on Information Policy (SCIP).

\section{Australian information infrastructure officer's role}

The post of Executive Efficer, Information Infrastructure Liaison was seen as one that would provide a specific focus for international collaboration, and also provide SCIP with input on the range of policy issues - intellectual property, distance education, copyright, library cooperation, authentication, $\mathrm{Y} 2 \mathrm{~K}$ issues - that it had to deal with on behalf of AVCC.

This article will concentrate on the main aim of the position - to support the developing focus on international collaboration. This involved wide-ranging consultation with and liaison between Australian stakeholders - CAUL, CAUDIT, AARNet, SCIP and, in the UK bodies such as JISC and its agencies including the electronic libraries programme (eLib) and the Combined Higher Education Software Trust (CHEST), and in the USA bodies such as the Association of Research Libraries (ARL) and $\mathrm{CNI}$. While most communication was by email, and telephone, there was a budget for travel as well. During July 1998, for example, the author made a three-week trip to the USA and UK to meet with officials from JISC, ARL and CNI, focusing on staff associated with the UK subject gateways, CHEST, eLib, and in the USA (apart from ARL and CNI) meetings with staff from two of the more influential academic library consortia. While a travel budget and face-to-face meetings were obviously necessary for making contacts in the USA and UK, it was also vital within Australia. The position was based at the University of Adelaide, some $800 \mathrm{~km}$ distant from the AVCC offices in Canberra, and further still from important centres such as Sydney and Brisbane. 
The first priority was to get clear the specific areas on which to focus, and within that group, concentrate on those that were most likely to yield results in a short space of time.

Discussion on the range of possible collaborative activity had ranged widely during the two meetings between CAUL and JISC. A senior CAUL member, Neil McLean, at the 1996 meeting, suggested several areas that could be tackled. He included the range of issues raised by the unsatisfactory status of the ownership of university-generated intellectual property. He also included cooperative networking strategies - such as mirroring between countries, co-development of "resource discovery" tools, such as metadata initiatives like the Dublin Core. Document delivery could be expanded beyond JEDDS to include both print and electronic library materials (McLean, 1996).

After the 1997 meeting, Kelly Russell, the JISC international coordinator, identified several areas of interest to the UK - again, intellectual property and co-development of subject gateways, but also a study on collaborative networking strategies and investigation of strategies and mechanisms for sharing digitised resources (Russell, 1997). To this was added the notion of sharing access to databases - effectively extending licences to access commercial databases between the UK and Australia. CAUL was also developing an interest in authentication systems for accessing remotely hosted databases, as it became clear that there were real problems in supporting distance education students needing access but dialing in to third-party Internet service providers. With publicity for JISC's ATHENS system starting to appear, and the announcement by CNI, in late 1997, of a study into authentication schemes, it was clear that this too was an issue for which collaborative effort might be appropriate.

Confirmation had now to be sought from the stakeholders that the issues discussed between CAUL and JISC were still relevant and achievable, and to gauge the scope of collaboration involved.

Once done, SCIP itself needed to assess how achievable these might be. A work plan was therefore developed that took in the need to visit sites in Australia, the UK and USA, to phone, e-mail and meet with all relevant people, to engage the interest of these major players - CAUL, eLib, CHEST - seek agreement between parties on a course of action, and then endorsement from either CAUL or the AVCC for the approaches being made.

However, the reality for 1998 was that the executive officer position was funded for 12 months only, at least in the first instance. It was therefore decided by SCIP to concentrate on only those areas that had some prospect of showing a clear return within that 12 -month period. Document delivery was not included in the work plan as it was already at a stage, through LIDDAS, where commercial agreements and support were becoming available.

The work plan consequently focused on assessing and, where possible, developing the potential for international collaboration in: multi-national purchasing consortia for access to scholarly databases; subject-based information gateways to quality-assured scholarly information on the Web; mirroring database resources between the UK and Australia; national or international systems to authenticate and authorise staff and students to use networked, licensed databases; making progress in the resolution of some or all of the issues involved in the "scholarly communications crisis".

\section{Multi-national purchasing consortia}

\section{Background}

CAUL began life in 1928 as a forum for Australian university librarians for the discussion of issues relating to libraries and a mechanism for the coordination of activities which benefit the university community. From the early 1990s, and reflecting the impact of the Internet, the notion of what could 
be achieved cooperatively had changed greatly, and had moved towards large-scale, national projects of immediate significance to the entire university community.

As we have seen, this was inspired in large part by the BIDS ISI Citation Index service.

CAUL had developed a new role, indeed a new life, as a consortium purchasing body on behalf of participating universities for expensive databases, starting in 1993 with Current Contents.

Despite this success, there were still, by early 1998, many databases long considered, in their paper form, as established and essential parts of conventional library collections, but which were now, in their Web incarnations, too expensive to contemplate for purchase either by CAUL or by the individual institutional members of CAUL.

At the same time, with library budgets on their ceaseless downward spiral, there were increasing concerns at the apparently growing concentration of ownership of scholarly publishing outlets among a few commercial information providers. These concerns converged on the proposed (but finally unsuccessful) merger in late 1997 between Elsevier and Wolters Kluwer. From a library perspective it was now becoming appropriate to think in terms of the creation of larger and larger buying groups through regional, national, and even transnational purchasing consortia and licensing agreements - as a corrective and counter-weight in negotiations with publishers and vendors.

In April 1998 the Australian Federal Minister for Education, David Kemp (1998), spoke on the opportunities for international purchasing collaboration that he believed Australia was missing out on, giving further impetus to the exploration of opportunities for collaboration with consortia internationally.

Working with CAUL's Committee for Electronic Information Resources (CEIRC) the task, in terms of the international collaboration initiative, was therefore to see how much potential there actually existed for further collaboration. This was done by direct e-mail, correspondence on the ICOLC mailing list, and personal meetings with consortium staff in the UK and USA.

Precedent certainly existed for such "multiconsortia" - CAUL and CONZUL (Committee of New Zealand University Libraries) already had joint agreements in place for LexisNexis and OCLC's FirstSearch datasets. In late 1997, CHEST (the Combined Higher Education Software Team, JISC's buying agent for the UK university sector) had negotiated a licence to extend access to the Beilstein CrossFire database from the UK universities to include Eire, and a large number of Swedish and Danish universities (Briggs, 1997).

During 1998, some important US academic library organisations became interested in the question of developing aggregations of consortia - "multi-consortia" - for particular purchases within the USA. First, SOLINET, the Atlanta-based group, successfully led a 23strong multi-consortial grouping in the USA to strike a deal with Lexis-Nexis (Young, 1998), a large and expensive data service also used in Australia. Second, ARL proposed a feasibility study for the creation of an organisational framework to support such activity, in the context of their general program to attack the root causes of the crisis in scholarly communications. ARL had, with the AAU (American Association of Universities), already identified the development of national and multinational consortia as one important way of helping to resolve the crisis (Association of Research Libraries, 1998).

Finally, the Consortium of Consortia $(\mathrm{CoC})$ grew from being a largely North American meeting ground for academic library consortia, into a global grouping when, in late 1997, the CoC discovered common cause with the authors of the Dutch/German licensing initiative (Dutch-German Library Joint Licensing 
Principles, 1997). With a name change to ICOLC (International Coalition of Library Consortia) there was suddenly a group representing academic library consortia worldwide. While really no more than an electronic forum for discussing common approaches to publishers, the appearance of ICOLC was a watershed, as it provided - through an e-mail list, a series of face-to-face meetings and, finally, a Web site - a vehicle for reaching potential partners relatively easily, and at a global level (International Coalition of Library Consortia, 1998a). The existence of an organisation of this kind also caught the attention of the major publishers, who felt themselves obliged to publicly respond to such ICOLC initiatives as the publication of the ICOLC "Statement of current perspective and preferred practices for the selection and purchase of electronic information" (International Coalition of Library Consortia, 1998b).

\section{Outcomes}

Contacts by the executive officer with directors of several US and UK consortia indicated some real interest in collaboration with CAUL. Some consortia were prepared to talk in specific terms about possible joint approaches to publishers and vendors. One such preliminary approach was made, but foundered because of the unwillingness of the publisher concerned to consider a multi-consortium arrangement that would compromise the interests of sales staff in regional offices set up with quite different assumptions about the size and nature of the global market. Another approach was stalled when the publisher was unable to make available a version of the product suitable for the Australian market.

General interest in the question of multiconsortial licensing saw the issue raised at a separate forum at the October 1998 ICOLC meeting in Denver. Here there was agreement that national and even multinational consortial deals were possible. It became clear, however, that there was no consensus on whether SOLINET-style deals were going to be routinely possible or desirable. Rather, it would be a question, in the short term, of consortia - perhaps through ICOLC - deciding which databases were likely prospects and with which other consortia it would make most sense to collaborate. Okerson, in her summary of the conference session on multi-consortia, said that the characteristics of a successful multi-library deal would likely include the presentation of a new product or new version of an existing product being launched (and therefore no existing market base to threaten), and would need to offer significant price savings and improvements in important licensing conditions to the consortia involved (Okerson, 1998).

\section{Subject-based information gateways}

\section{Background}

There have been initiatives in both the UK and USA to develop Web-based databases - called variously subject gateways or subject-based information gateways - which organise access to useful "free-toair" scholarly information relating to broad subject areas - e.g. chemistry, engineering, medicine. Such gateways differ from the standard Internet search engines in being highly selective, with selection of resources being done by humans (rather than uncritically by machine). In fact, the value they seek to add is based on explicit selection criteria relevant to teaching and research in higher education. By cooperatively dividing selection/ description responsibilities between research librarians and academics from a number of universities they more effectively exploit existing staff resources in providing enhanced description, indexing and timeliness, and by reducing the duplicated effort usually evident when each institutional library develops its own gateway services.

In the USA, there have been both local and regional initiatives, such as INFOMINE, and HealthWeb, as well as publicly funded national research initiatives such as SCOUT. 
In the UK, the concept was taken further through the funding provided under Follet for a series of UKbased, subject-specific subject national gateways (eLib, 1998). Run from JISC's eLib program, the UK gateways were funded to undertake developmental work. With an elaborate marketing and training infrastructure, they were based quite consciously on the notion of providing service to the entire higher education sector in the UK, and becoming one part of the solution to the problem of managing scholarly information available via the Web.

They also provided a potent and visible example for Australian university librarians to follow. So much so that, by December 1998, three Australian federal government Research Equipment and Infrastructure Fund grants have been made to develop cooperative Australian gateways to information in chemistry (MetaChem), agriculture (Agrigate) and, from 1999, engineering.

The desirability of cooperation between the UK and Australian gateways had long been discussed. Collaborative activity, it was felt, could include the development and application of emerging standards in resource description (so-called "metadata"), the development of cross-search capability between Australian and UK and US gateways, the mirroring of gateways, and direct input of cataloguing data to UK gateways from Australia, and into Australian gateways from the UK.

With the grant-funded development phase of the elib gateways coming to an end in 1998/99, JISC was faced with the question of how (or if) to make the services sustainable. Precisely because the eLib gateways had successfully made themselves part of the UK university information infrastructure JISC, in October 1998, committed itself to the continued support of the most successful of the gateways. JISC's strategy was to focus energy on areas where it could provide excellent content for the UK HE community, and where it could not, to collaborate with gateway providers overseas - whether in Australia, the USA or elsewhere in the English-speaking world (Joint Information Systems Committee UK, 1998a).

In fact, the JISC international coordinator had already facilitated the creation of collaborative links in 1997 between SOSIG (the Social Sciences Information Gateway) and the NSFfunded SCOUT service, the first fruits of which had been a mutual mirroring collaboration.

Outcomes Following some meetings and correspondence between AVCC, JISC and SCOUT staff, a formal meeting of representatives from Australia, the UK, the USA and Scandinavian countries took place in September 1998. From this meeting emerged a loosely-structured program called IMesh which provides the framework - through a Web site (IMesh, 1998), e-mail list and a proposed series of workshops - for the development of an international consensus on how collaborative activity will occur over the coming years.

The first IMESH workshop is planned for June 1999 in the UK (IMesh Framework Workshop, 1999). Issues that the Workshop series will address include the development of a comprehensive guide to what is available and where; the production of guidelines in the creation, costing and management of gateways; an exploration of the issues surrounding quality assessment and agreements over quality criteria for partnerships' collaborative efforts, and a discussion of the question of scope. While the UK gateways and SCOUT have concentrated on research material, others are interested in servicing undergraduate and school-based populations.

\section{Mirroring databases}

\section{Background and outcomes}

Given the cost and performance incentives to the university sector to use resources available in Australia before using resources available from overseas (a 6:1 cost-per-unit-volume differential in 
favour of internal traffic), the possibility of mirroring datasets (such as UK/ US subject gateways) in Australia was seen as a priority area. This strengthened when it became clear that the UK would move to a similar regime for cost containment.

It was, however, clear that CAUL itself was actively interested in the question of mirroring licensed, commercial datasets acquired through the CAUL consortium.

During 1998 the UK was still considering its policy on mirroring, and was then focused on FTP archives, rather than databases. The notion of the mirroring project therefore narrowed its focus, and concentrated on the mutual mirroring of subject gateways.

Data on the level of use from Australia of the major UK gateways were gathered, as was information on the interest/willingness of the UK subject gateway managers to provide mirrors of their resources. While Australian use of the major eLib gateways was running at around 2-4 percent of the worldwide total, the cost savings were nugatory, and likely to be eaten up by the costs of the mirroring operation itself. The real purpose of mirroring would be to promote the gateways themselves, and the principles of cooperative effort that underlay them, to improve system response from a client perspective, and to encourage the mirroring of Australian gateways in the UK.

Concrete interest at a national level in mirroring only began to crystallize once the CAUL executive decided, in late 1998, to pursue a general strategy for mirroring commercial datasets, in collaboration with CAUDIT. The CAUL executive felt that subject gateway mirroring should ideally form part of this national strategy.

\section{Authentication}

\section{Background}

Reliable access to networked resources for staff and students dialing-in from off-campus has become a matter of concern worldwide. Existing solutions assume that all dial-in users are connecting to the Internet through the same service provider - the university. In fact, both staff and students are using a growing variety of commercial providers. Given the prevailing reliance by commercial service providers on limiting access to a given range of Internet addresses - usually the client university's net- work address range - it has become more and more difficult to provide university members with access to the full range of networked resources for which they are authorised.

Both JISC in the UK and CNI in the USA were, in 1997-1998, developing solutions or seeking to provide advice on best practice for their constituents. JISC was interested in providing their solution, the ATHENS national authentication system to Australia. ATHENS is a system, available to the entire UK higher education sector, that seeks to provide users with a "single sign-on" to authenticate themselves and gain access to all the networked resources - and especially library databases - for which they are authorised (National Information Services and Systems UK, 1999). CNI meanwhile was undertaking a review of all available solutions (including ATHENS) and promised to provide a testbed program for their preferred solution (Coalition for Networked Information, 1998). A draft "White paper on authentication and access management issues in cross-organisational use of networked information resources" was published to the Web (Lynch, 1998) as part of the CNI program.

Coincidentally, CAUDIT, through Griffith University, had begun a review of "off-theshelf" systems to simplify the process of authenticating users to institutional networks. Given CAUL's interest in providing access to database services hosted overseas, it was decided to broaden the scope of the CAUDIT study to include the broader problem of access to the services of remote commercial providers. 
The aim of this element of the AVCC international collaboration project became, then, to explore the possibilities for international cooperation among the USA, UK, and Australia in the evaluation and development of user authentication systems, and the means by which international experience could be incorporated into the CAUDIT study.

\section{Outcomes}

The executive officer was invited to join the steering committee of the CAUDIT/CAUL authentication system project, to provide input on these international developments. The CAUDIT/CAUL study of "single sign-on" authentication systems for Australian universities was completed in December 1998. The report concluded that, in the heterogeneous university networking environment, the achievement of a single log-on process for every end-user is unlikely or impossible. Nevertheless, the report endorsed a national approach to the problem of guaranteeing access to remote networked services, and said that a multiinstitutional project team of Australian university library and IT staff should be formed to fully explore the issues surrounding the national deployment of ATHENS (Council of Australian University Directors of IT, 1998).

Following discussion between CAUL and CAUDIT representatives it was decided to extend the Authentication System Project, along the lines of the project recommendation above, by seeking federal government funding. An Australian federal government research infrastructure grant was awarded to CAUL and CAUDIT in December 1998. The study, "Management of access to networked information resources", will look specifically at the creation of a "national access management system", focusing on the issues surrounding the creation of a national authentication framework for access to remotely-hosted database and e-journal services. ATHENS will serve as the benchmark for the project (Council of Australian University Librarians, 1998). Should ATHENS emerge as the system of choice, then further collaborative opportunities between JISC and Australian partners may emerge.

\section{Scholarly communications crisis}

\section{Background}

The "scholarly communications crisis" incorporates a number of different issues, including library funding, the increasing commercialisation and concentration of ownership in academic publishing, rising publication costs and the ownership and management of intellectual property and peer review in both the paper-based and electronic publishing environments.

There is a growing awareness in Australian universities that access to scholarly literature is endangered by these trends and issues. Indeed, the Australian academic library community, through CAUL, has been energetic in ensuring that this has happened. For example, in 1992, the National Scholarly Communications Forum was established by the learned societies, CAUL, the National Library and other bodies interested in scholarly communication. The forum has hosted a series of roundtables to highlight specific issues and has gradually raised the level of awareness among senior academics (Williamson, 1997).

The crisis was not initially identified by AVCC as an area for international collaborative effort, being seen as too large and too complex to yield results within 12 months. However, the CAUL and CAUDIT executives referred the issue(s) to SCIP, and it was also the subject of separate action, through the creation of an "Australian universities fighting fund" organised by Colin Steele, the Australian National University Librarian, on behalf of several of the larger research-oriented Australian universities and research organisations (Simmonds, 1998). 
With the appearance, in April 1998, of the Pew Report and Recommendations (To Publish and Perish, 1998) under the joint auspices of the ARL and the Association of American Uni- versities (AAU), it appeared that a model might exist for a body like AVCC to address at least some of the problems associated with the crisis. In fact, through its consideration of international purchasing consortia for library materials, and the need to revise its 1995 discussion paper "Ownership of intellectual property in universities" (Australian Vice-Chancellors' Committee, 1995), AVCC was already considering the subject-matter of two of the five recommendations of the Pew Report. In fact, Pew seemed to provide a broader intellectual framework into which AVCC considerations could sensibly fit.

In the UK, JISC had already developed a policy stance in line with the Pew Report and, through its senior management briefing paper series, was already advising academics to licence content to commercial publishers, rather than uncritically hand over control of copyright (Joint Information Systems Committee UK, 1998b).

\section{Outcomes}

The executive officer tracked the response to the Pew Report through ARL and AAU, and reported progress to SCIP. This helped to raise the profile of the scholarly communications crisis, and the various issues surrounding it, both within SCIP and within the AVCC. SCIP publicised the Pew Report and its recommendations to all members of the AVCC. SCIP also persuaded AVCC to endorse ARL's SPARC initiative (SPARC is an attempt to encourage scholarly society publishers to provide direct - and much cheaper - competition to the large publishers, such as Elsevier, and was inspired by one of the five Pew recommendations). At much the same time, CAUL took out an affiliate membership with SPARC. Finally, it appears possible that the issues surrounding the use and ownership of intellectual property in research papers will be incorporated into SCIP's reconsideration of the AVCC's "Ownership of intellectual property in universities" discussion paper in 1999.

The activities of the Australian universities fighting fund are also highly relevant here. In early 1999, the "fighting fund" group held a workshop which brought together academics, including the membership of SCIP, higher education sector bureaucrats, research funding administrators and librarians.

Several significant outcomes resulted from the workshop. There was, for example, a tacit recognition that the issues were a "university problem" not a "library problem". There was also recognition that it was an international issue which necessitated liaison with the scholarly community throughout the world but particularly in North America, the UK and Europe (McLean, 1999b).

\section{Problems with the position/postscript}

It is ironic that a role such as one in international liaison in information infrastructure - a job created by and for the Internet - should fall, in a sense, victim to one of the less felicitous aspects of the virtual existence.

As already described, it had been decided, because of the availability of only short-term funding, that the job would be offered to candidates anywhere within Australia, but reporting to the AVCC in Canberra. As it happened, the executive officer was based in Adelaide, a city some $800 \mathrm{~km}$ distant from Canberra. The decision to make the job more or less completely virtual, otherwise an imaginative response to the financial realities, had the unintended side-effect of creating a sense of professional and personal isolation. The nature of the job as a liaison position really required an insider's understanding and perspective, and this was hard to acquire from a remote location. It became clear that the position, to better serve the needs of the AVCC, would be more appropriately relocated to Canberra, and so the decision was made to do this, assuming funding, from 1999. 


\section{Conclusions}

The executive officer position - to the extent that it symbolises attempts at formalising collaborative relationships in information infrastructure at a nation-to-nation level - is very much a work in progress. If the main aim of this type of international collaboration is to provide for the Australian academic community access to quality-assured scholarly information more quickly, more cost-effectively, and more reliably, then it became clear during the year that the notion of achieving direct returns within 12 months was not realistic. In part this was because, at least within Australia, what had at first seemed to be issues involving international liaison, were in fact issues that first required the development of a national approach and therefore national coordination.

There is, because of the global interconnectedness that the Internet creates, more and more potential for, and need for, collaboration. It is not clear, however, if at this stage of development, purely formal attempts at coordination, as conceived in the UK and Australia in 1997 and described in this article, are always going to be the most productive and appropriate ways to achieve these ends. JISC, for example, while it has retained the function of international liaison, no longer has a separate officer specifically devoted to this role. It is now part of the portfolio of responsibilities of the JISC head of programs. Indeed the international relations role is seen more as one of coordination, with active liaison being left to staff more directly involved at a specific project level.

It also became clear during 1998 that there was already much international liaison going on at an informal level, and at a project-to-project level. The JEDDS/LIDDAS/PRIDE work is an excellent example of this.

Where liaison at a high level did appear to offer scope was with subject gateways, not least because of the way in which the UK is organised - centrally - and because of the adoption of a centralised management model for the elib gateways in the recently created resource discovery network. The handling of the questions surrounding the scholarly communications crisis also appears to require high level national and international coordination.

Nevertheless, there have been gains made during the year. It seems that multi-consortial approaches to database acquisition are possible, and are being considered. Subject gateways now have a framework in which to internationalise, set standards and recruit new members. And, at least for Australians, an informed, academy-wide debate over the ownership and management of intellectual property generally seems to have been joined.

With greater recognition of the issues and the growing urgency of strategic action by Australian scholars, the need for international liaison is indeed evident. Acting by themselves, Australian libraries and universities cannot expect to have much impact especially on the large commercial publishers. Effective alliances with their counterparts in North America, the UK and Europe will become not just desirable but a matter of survival (McLean, 1999b).

\section{References and further reading}

Association of Research Libraries (1998), ARL/AAU Pew Roundtable Recommendations and Follow-up, (ac- cessed 9 March 1999). Available: http://www.arl.org/ scomm/pew/recommend.html\#rec2 Australian Vice-Chancellors' Committee (1995), Ownership of Intellectual Property in Universities, (accessed 9 March 1999). Available: http://www.avcc.edu.au/avcc/ pubs/ooipiu.htm

Australian Vice-Chancellors' Committee Standing Committee on Information Resources (1998), Library Infrastructure Projects (funded by the National Priority (Reserve) Fund 1994-1997), (accessed 9 March 1999). Available: http://www.anu.edu.au/caul/org/scir.htm 
Beyond the Beginning: the Global Digital library (1997), (accessed 9 March 1999). Available: http://www. ukoln.ac.uk/services/papers/bl/blri078/content/

Briggs, S. (1997), Beilstein Information and CHEST UK agree National Deals with Sweden and Denmark for the Provision of CrossFire and Associated Datasets, (accessed 9 March 1999). Available: http://www. beilstein.com/beilst_3.html

Coalition for Networked Information (1998), The CNI Program on Authentication, Authorization and Access Management, (accessed 9 March 1999). Available: http://www.cni.org/projects.authentication/

Council of Australian University Directors of IT (1998), CAUDIT/CAUL Authentication System Project, (accessed 9 March 1999). Available: http:// www.gu.edu.au:81/uls/sso/

Council of Australian University Librarians (1998), Management of Access to Networked Information Resources (User Authentication): CAUL/CAUDIT Application for RIEFP Funding for 1999 (Funding awarded 2/12/98), (accessed 9 March 1999). Available: http://www.anu.edu.au/caul/cauldoc/authenticat-rief.htm

Dutch-German Library Joint Licensing Principles and Guidelines (1997), (accessed 9 March 1999). Available: http://cwis.kub.nl/ dbi/english/license/ licprinc.htm

eLib Electronic Libraries Programme: Project Details (1998), (accessed 12 March 1999). Available: http://www.ukoln.ac.uk/services/elib/projects/

IMesh (1998), IMesh: International Collaboration on Internet ubject Gateways, (accessed 9 March 1999). Avail- able: http://www.desire.org/html/subjectgateways/ community/imesh/

IMesh Framework Workshop: A Workshop Organised by the Resource Discovery Network Centre (RDNC) on behalf of the IMesh Initiative with JISC Support (1999) (accessed 20 May 1999). Available: http://www. ukoln.ac.uk/events/imesh-workshop-jun99/intro.html

International Coalition of Library Consortia (1998a), About the International Coalition of Library Consortia (accessed 9 March 1999). Available: http:/www. library.yale.edu/consortia/

International Coalition of Library Consortia (1998b), Statement of Current Perspective and Preferred Practices for the Selection and Purchase of Electronic Information, (accessed 12 March 1999).

Available: http:// www.library.yale.edu/consortia/statement.html

Joint Information Systems Committee UK (1998a), Subject Based Information Gateways: Resource Discovery Network, Electronic Information Development Pro gramme: eLib Phase 3c, (accessed 9 March 1999). Available: http://www.jisc.ac.uk/pub98/c10 98.html

Joint Information Systems Committee UK (1998b), Copy- right, (accessed 9 March 1999). Available: http:// www.jisc.ac.uk/pub98/sm05 )copyright.html

Joint Information Systems Committee UK (1999), JISC Services, (accessed 9 March 1999). Available: http:// www.jisc.ac.uk/services/index.html

Kemp, D. (1998), Strategic Developments in Higher Education, (accessed 9 March 1999). Available; http:// www.detya.gov.au/ministers/kemp/ks210498.htm 
Lynch, C. (1998), "A White Paper on authentication and access management issues in crossorganizational use of networked information resources", (accessed 9 March 1999). Available: http://www.cni.org/projects/ authentication/authentication-wp.html

McLean, N. (1996), Closing Session Summary, Round Table No. 5 of the National Scholarly Communications Forum, Canberra, 21-22 October, (accessed 9 March 1999). Available: http://www.anu.edu.au/caul/nscf/ mclean.htm

McLean, N. (1999a), "Creating information futures: the quest for sustainability", Information Online \& On Disc 99: the 9th Australasian Conference \& Exhibition, Sydney, January 1999.

McLean, N. (1999b), Strategic Directions for Australia's Research Information Infrastructure, summary of the Project Workshop "Australia's Information Future Innovation and Knowledge Management for the 21st Century", organised by the Australian University Libraries Fighting Fund, (accessed 17 March 1999). Available: http://www.lib.mq.edu.au/McLean/ directions/

Morrow, T. (1992), "BIDS ISI - a national experiment in end user searching", Electronic Networking: Research, Applications and Policy, Vol. 2, pp. 61-73.

National Information Services and Systems UK (1999), ATHENS Access Management: General Information, (accessed 12 March 1999). Available: http:// www.athens.ac.uk/info/

Okerson, A. (1998), Meeting Reports from Denver ICOLC, 13 October, in summary, (accessed 9 March 1999). Available: http:/www.library.yale.edu/consortia/Denver987th.html

Rusbridge, C. (1998), "Towards the hybrid library", D-Lib Magazine, (accessed 9 March 1999). Available: http:// mirrored.ukoln.ac.uk/lis-journals/dlib/dlib/dlib/july98/ rusbridge/07rusbridge.html Russell, K. (1997), "IISC/CAUL collaboration agreement", Ariadne, (accessed 9 March 1999). Available: http:// www.ariadne.ac.uk/issue10/kelly-press/intro.html

Shipp, J. (1996), Overview of the 5th Roundtable of the National Scholarly Communications Forum, Canberra, 21-22 October, (accessed 9 March 1999). Available:

http://www.anu.edu.au/caul/nscf/shipp.htm

Simmonds, S. (1998), “Libraries cut \$7m after fall in dollar", ANU Reporter, Vol. 29, (accessed 9 March 1999). Available: http:/www.anu.edu.au/pad/ANURep/V29/14/library.html

To Publish and Perish (1998), (accessed 9 March 1999). Available: http://www.arl.org/scomm/pew/ pewrept.html

Williamson, V. (1997), The Beginnings of the Scholarly Communication Movement in Australia, (accessed 16 March 1999). Available:

http:/www.curtin.edu.au/curtin/library/publications/vwiatul97.html

Wiseman, N. (1998), "International collaboration on subject based Internet gateways", D-Lib

Magazine, (accessed 9 March 1999). Available:

http://www.dlib.org/dlib/october98/10clips.html\#GATEWAYS

Young, J.R. (1998), "600 colleges and universities to gain access to a huge database", Chronicle of Higher Education, 3 July, p. A20. 282 


\section{University Library}

\section{- M M I N E R VA A gateway to Melbourne's research publications}

Minerva Access is the Institutional Repository of The University of Melbourne

Author/s:

Cramond, Stephen

Title:

Efforts to formalise international collaboration in scholarly information infrastructure

Date:

1999

Citation:

Cramond, S. (1999). Efforts to formalise international collaboration in scholarly information infrastructure. Library Hi Tech, 17(3), 272-282.

Publication Status:

Published

Persistent Link:

http://hdl.handle.net/11343/32747 